\title{
Construction of a Performance Assessment Model for Zakat Management Institutions
}

\author{
${ }^{1}$ SRI FADILAH, ${ }^{2}$ KANIA NURCHOLISAH, ${ }^{3}$ RINI LESTARI \\ 1,2,3 Fakultas Ekonomi dan Bisnis, Universitas Islam Bandung Jl. Taman Sari No.1 Bandung 40116 \\ email: ${ }^{1}$ srifadilah71@yahoo.com
}

\begin{abstract}
The objective of the research is to examine the performance evaluation using Balanced Scorecard model. The research is conducted due to a big gap existing between zakat (alms and religious tax in Islam) with its potential earn of as much as 217 trillion rupiahs and the realization of the collected zakat fund that is only reached for three trillion. This indicates that the performance of zakat management organizations in collecting the zakat is still very low. On the other hand, the quantity and the quality of zakat management organizations have to be improved. This means the performance evaluation model as a tool to evaluate performance is needed. The model construct is making a performance evaluation model that can be implemented to zakat management organizations. The organizational performance with Balanced Scorecard evaluation model will be effective if it is supported by three aspects, namely: PI, BO and TQM. This research uses explanatory method and data analysis tool of SEM/PLS. Data collecting technique are questionnaires, interviews and documentation. The result of this research shows that PI, BO and TQM simultaneously and partially gives a significant effect on organizational performance.
\end{abstract}

Keywords: zakat, zakat organizations and organizational performance.

\section{Introduction}

This study is a continuation of previous studies related to the zakat management model with the good governance of Amil Zakat Organization (LAZ). After the LAZ management model is found out, this study is aimed at learning more about the assessment of LAZ performance using Balanced Scorecard model. The background of this research is the issue that related to the concept of zakat implementation as an individual's religious obligation and as a common public financial component. Regulation number 23 of 2011 about zakat management has become a strong legal protection for the zakat management in Indonesia. This is triggered by the gaps between the potential zakat that is as much as 217 trillion with the funds that are collected which only reached for 3 trillion. It showed a very low performance in collecting the zakat.

To overview the performance of LAZ comprehensively, a balanced scorecard model (Rohm: 2004) is used. It is a model of an organizational performance assessment that includes financial and non-financial perspectives (Customers and Stakeholders, Internal Business Process and Employees and Organization Capacity). In fact, many obstacles can hinder the implementation of balanced scorecard model, especially LAZ. Therefore, we need to find out the factors that influence the implementation of balanced scorecard model to improve the performance of LAZ. There can be many factors that influence the application of balanced scorecard model, but allegedly the following factors that influence the implementation of balanced scorecard models are: the implementation of internal control (Christian Herdinata, 2008: 14-15), the implementation of organizational culture (Apfelthaler, Muller and Rehder.2002: 108 ) and the implementation of total quality management (Samdin, 2002: 19).

Many models are used to assess a performance. One of them is balanced scorecard. The balanced scorecard is a management system of measurement and

Received: August 02, 2016, Revision: November 10, 2016, Accepted: December 19, 2016

Print ISSN: 0215-8175; Online ISSN: 2303-2499. Copyright@2016. Published by Pusat Penerbitan Universitas (P2U) LPPM Unisba Accredited by DIKTI. SK Kemendikbud, No.040/P/2014, valid 18-02-2014 until 18-02-2019 
control that can quickly, accurately and comprehensively provide insight to managers about business performance. Balanced Scorecard is a management concept of contemporary performance that now is widely applied in public organizations, including government organizations and is applied in Zakat Management Organizations such as LAZ and BAZ. Balanced Scorecard is considered appropriate for public organizations because balanced scorecard does not only emphasize the quantitative and financial aspects but also the qualitative and non-financial aspects. Kaplan and Norton (1996: 102) indicate that balanced scorecard provides executives a comprehensive framework to translate the organization's vision and strategy into a comprehensive set of integrated performance measures. Balanced Scorecard translates the mission and strategy into some objectives and measurements that are structured into four perspectives, namely: finance customers and stakeholders, internal business process, as well as employees and organization capacity. The focus of public organizations is the organization's mission that is to serve and improve the welfare of the community. The mission is formulated into strategies to achieve its mission, with explanations and figures as follows: (1) Customers and Stakeholders Perspective the reviews from customers and stakeholders perspective in a public sector organization are held to find out how customers and stakeholders view the organization. Customers and stakeholders in the public sector are taxpayers and public service users. For a zakat management organization, muzaki is a person who gives zakat and mustahik is the recipients of ZIS (Zakat) funds. Customer and stakeholder satisfaction and perspective can be measured as follows: (a) citizen satisfaction; (b) service coverage; and (c) quality and standards. (2) Financial Perspective. Financial perspective in public organizations is used to address how organizations increase their revenue and reduce the management costs and how we view zakat donors. Financial perspective explains the expectation of (LAZ) muzaki as a financial resource. Thus, financial perspective can use the following measurements: (a) Efforts to improve the amount of zakat funds that are collected and enforced; (b) Affectivity of services; (C) The increased amount of zakat funds collected; and (d) the increasing number of zakat that is empowered. (3) Internal Business Process Perspective. Internal business process perspective tries to build organizational excellence by improving internal business process continuously. The strategic objective of internal business process perspective is to support customers and stakeholders' perspective and financial perspective. In internal business process perspective, in order to improve its performance, public sector organizations should identify and measure the core competence of the organization, identify the main process of service, identify the main technology that should be owned and define the performance measurement and performance target. Thus, internal business process perspective can be measured as follows: (a) The innovation of product; and (b) Management Information System. (4). Employees and Organization Capacity Perspective. Internal business process perspective, customers, and stakeholders' performance used on balanced scorecard to identify the parameters for building organizational excellence. The target and size of success will continue to change as time changes. Therefore, organizations must be able to innovate, create and learn. The strategic goals and objectives that are set in employees and organization capacity perspective will affect other perspectives which are internal business process perspective and customers and stakeholders' performance. Therefore, a performance measurement of employee and organization capacity can use: (a) Skill coverage; (b) income and welfare personnel; and (c) Personal satisfaction.

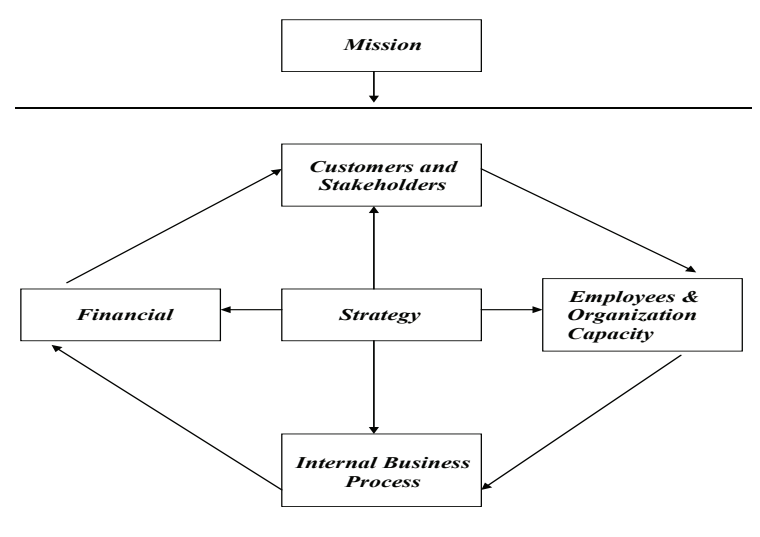

Source: Rohm. Howard (2004) Figure 1 Balanced Scorecard for Public
Organization

The first factor that affects organizational performance in zakat management organization, LAZ in particular is an internal control. According to Committee of Sponsoring Organizations of the Treadway Commission 
(Coso. 2004: 13) which is also cited by the Indonesian Institute of Accountants (IAI.2012: 319.2) stated that it is important for all managers to understand the importance of the implementation and maintenance of effective internal control which has become their responsibility. To achieve the objectives of internal control, COSO (2004: 16-18) explains the components of internal control, as follows: environmental control, risk assessment, controlling activities, information and communication, and monitoring.

Furthermore, the second factor that might influence the organizational performance of zakat management organization (LAZ in particular) is organizational culture. According to Kreitner (2008: 72). Organizational culture has an important function in organizations where organizational culture serves as a mean to unite the members of the organization that consists of a set of individuals with different backgrounds. On the other hand, according to Apfelthaler, Muller and Rehder (2002: $108)$, organizational culture can improve its excellence to win the completion by improving organizational performance. The results of Flamholtz (2001: 266-273) has stated that organizational culture affects organizational performance through management process and system. The results of the previous research show that organizational culture can improve organizational performance through a certain media such as compatible management, system and processor, and organizational governance. Organizational culture for LAZ, is called organization culture because LAZ is a non-government organization in social and religious fields. LAZ is an (business) organization that works horizontally and bonds by vertical laws (Islamic/Shariah compliance). The dimension or main characteristic of organizational culture that can be measured is revealed by Robbins (2010:510) which includes seven characteristics, which are: (1) Innovation and risk taking, i.e. the extent to which employees are encouraged to innovative and take risks; (2) Attention to detail, is the extent to which employees are expected to show a precision analysis and attention to details; (3) Outcome orientation, is the extent to which management focuses on results rather than on the techniques and processes used to achieve those results; (4) People orientation, is the extent to which management decisions take into account the effects of the outcomes of people within the organization, (5) Team orientation, is the extent to which activities are organized into teams rather than individuals; (6) Aggressiveness, is the extent to which people are aggressive and communicative rather than relaxed; (7) Stability is the extent to which the organization's activities emphasize the maintenance of the status quo as a growth contrast.

These seven characteristics describe the organizational culture and become the basis of common understanding among the members about the organization and it reflects the power that should be owned which can be illustrated as follows:

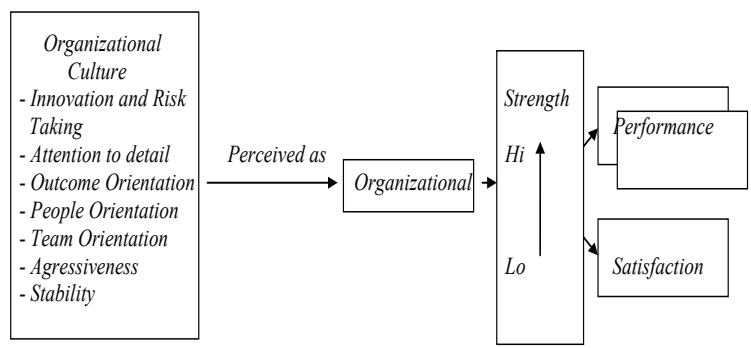

source: Robbins, Organizational Behavior. 2010: 265

Figure 2. Relationship between organizational culture and organizational performance

Figure 2 depicts that employees form an overall subjective perception of the organization based on factors such as risk tolerance, the pressure on the team and support. This overall perception, then, becomes organizational culture. The perception that supports or the one that does not support this will influence employee performance and satisfaction. Performance and satisfaction will increase in the form of stronger organizational culture.

Finally, the third factor considered to influence the organizational performance of LAZ in particular, and zakat management organizations in general, are total quality of the management. Total Quality Management (TQM) is a management model of doing business to achieve good governance through continuous improvement of the products, services, people, processes and environment. Implementing of TQM model can create better zakat fund management, donation and shadaqah and, ultimately improve the performance of LAZ. On the other hand, many private zakat institutions are founded and it will result in a high level of competition among zakat management institutions (LAZ). 
In order to be survived, able to compete and improve their performance, LAZ and other zakat management institutions should improve their internal management in order to reclaim the public trust. One effort to create good zakat fund management is to implement TQM. TQM is a management model of doing business that maximizes organizational competitiveness through continuous improvement of the products, services, people, processes and environment. Furthermore, according to Samdin (2002: 19) There are several reasons of why TQM needs to be applied in zakat management of LAZ, which are: (1) to improve competitiveness and leading the competition; (2) to generate the best output of LAZ; (3) to gain the trust of muzaki (donators) who's funds are distributed to the right people or groups; and (4) to improve the quality of zakat management that ultimately improves customer and public satisfaction.

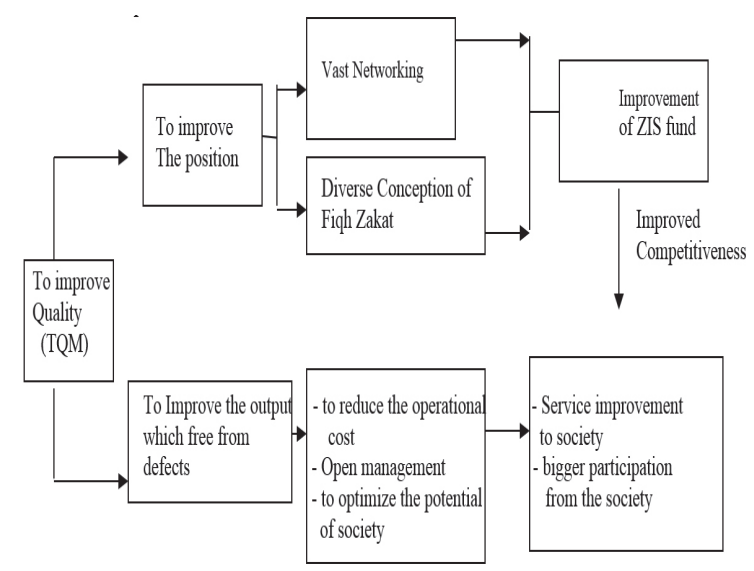

Source: Budi Budiman:2002

Figure 3: ZIS Fund Management Improvement Strategy With Key Benefits Approach Total Quality Management (TQM)

According to Tenner and Detoro (2008: 32), TQM has three basic philosophies that can be drawn on as a meeting point of various opinions about TQM as follows: (1) Focusing on customer satisfaction (customer Focus) Internal customers are workers or departments that are involved in the process of production / creation of services. External customers are people or organizations that buy and use a company's products or services. Tenner and Detoro (2008: 51-93) reveal that the formation of customer focus includes in three main activities, namely (a) to identify the customers; (b) to understand and meet the expectations of customers; (c) to provide a mechanism to hear what customers want; (2) Empower and involve employees. According to Budi( 2002: 16), the attempts to improve the quality continuously can be achieved in two ways, as follows: (a) LAZ can make a strategic position in ZIS management by socializing the Islamic law (figh) concept more properly; (b) LAZ can improve the results that are free from defects that can inhibit the institutional operational.

In this research, consumer confidence is not a variable that affects organizational performance but is included only to explain that a good or high organizational performance will increase public or society trust, especially consumer trust. The consumers that are referred to in organizational management, are zakat management organizations such as public especially muzaki and mustahik.

There are many definitions of consumer trust.

Kreitner and Kinicki (2001: 422) argued that consumer trust is the trust given by one party concerning the purpose and behavior of other consumers. Consumer trust is a quality also defined as a provider of a product or service that can be trusted or relied upon to fulfill their pledge (Sideshmuhk. et al. 2002: 17). Peppers and Rogers (2004: 71) proposed similar definition; consumer trust is a quality that reflects one's good relationship with others. Consumers give trust to the organization through the activities of the organization.

Effective marketing depends on the development and management of consumer trust so that consumers specifically will buy or use a service before experiencing It. (Shamdasani and Balakrishan, 2000: 403). Kreitner and Kinicki (2001: 422) stated that consumer trust is the trust of a party concerning the purpose and behavior of the other party. Conceptually, Morgan and Hunt (1994: 23) stated that consumer trust will exist if one party has trust in the integrity and reliability of other parties.

Therefore, it can be explained that Balanced Scorecard is a contemporary management concept that has started to be widely applied in public organizations, including government organizations and Zakat Management Organizations (OPZ) such as LAZ and BAZ. Balanced scorecard (Rohm: 2004) aims to translate the mission and strategy into objectives and measures that are structured into four perspectives, namely: financial customers and stakeholders, internal business process, as well as employees and, organization capacity. Many factors affect the realization of high-performance assessments 
using balanced scorecard model including the implementation of internal control. In order to be able to apply the performance assessment using Balanced Scorecard model, controlling and supervising are needed. According to the Committee of Sponsoring Organizations of the Treadway Commission (COSO. 2004: 13), which is also cited by the Indonesian Institute of Accountants (IAI. 2012: 319.2), internal control is essential for all managers in the organization to understand the importance of implementing and maintaining effective internal control which is their responsibility. This is consistent with Fadilah (2011: 11) who has stated that internal control and TQM improve (good governance) which has a positive impact on organizational performance. To achieve internal control objectives, the components of internal control are explained as (1) control environment; (2) Risk assessment; (3) control activities; (4) Information and communication; and (5) monitoring.

The next thing that affects the application of balanced scorecard model for performance assessment is organizational culture. This is due to the statement that ethics has become the basis of performance assessments using balanced scorecard model. Internally, ethics both in the form of ethical values and norms become part of organizational culture. Organizational culture is a set of values and norms that are widespread and control the interaction between members of the organization with people who are outside the organization's environment. Zabid et al (2003: 56), links organizational culture to organizational performance. To create a good management system that produces high organizational performance, management must be supported with strong characteristics of organizational culture. According to Robbins (2010: 210) it includes seven characteristics, namely: (1) Innovation and risk taking, which is the extent to which employees are encouraged to innovative and take risks; (2) Attention to detail, is the extent to which employees are expected to show precision analysis and attention to details; (3) Outcome orientation, is the extent to which management focuses on results, not on the techniques and processes used to achieve the results; (4) People orientation, is the extent to which management decisions take into account the effect of the results on the people in the organization;(5) Team orientation, is the extent to which work activities are organized as teams rather than individuals;
(6) Aggressiveness, is the extent to which people are aggressive and communicative rather than relaxing; and (7). Stability is the extent to which an organization's activities emphasize maintaining the status quo.

Another factor that affects the performance assessment with balanced scorecard model is the implementation of total quality management. Since the application of total quality management has an impact on the process of continuous improvement of procedures, activities and policies are created to form the quality of human resources. It is consistent with the results of Hoque (2003: 43) and Sri Fadilah (2012: 12). Meanwhile, according to Tenner and Detoro (2002: 32 ), total quality management has three basic philosophies, namely: (1) focus on customer satisfaction; (2) empowerment and employee involvement; (3) continuous quality improvement. Furthermore, the efforts to improve the quality continuously in LAZ can be achieved in two ways (Samdin: 2002: 23 ): first, LAZ can take a more strategic position in ZIS management by disseminating the conception of Islamic law (fiqh) more appropriate. Secondly, LAZ can improve the results that are free from defects that can affect the organization's operations, namely, to have an impact on the reduction of operating costs, the creation of transparent management and the realization of all potentials that exist in society as clerics, scholars and professionals.

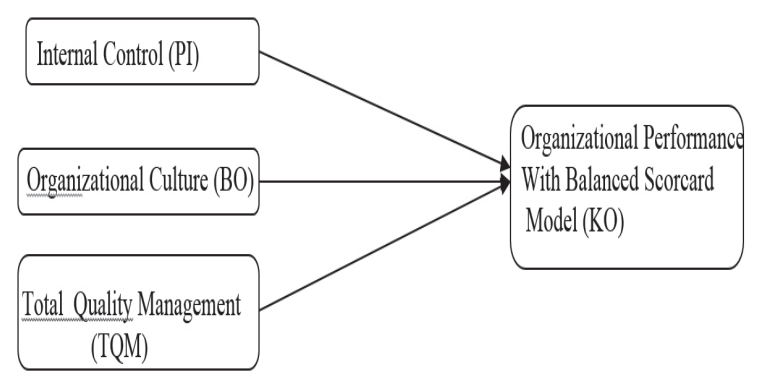

Figure 4. Framework

Based on the literature review and research framework, the research hypothesis is formulated as follows: there are effects of internal control, organizational culture and total quality management on organizational performance using balanced scorecard model simultaneously and partially.

Based on the research urgency and framework, this research will analyze the effects of the implementations of internal control, organizational culture and total quality management on the organizational 
Table 1

Test Results Reliability and Test Research Questionnaire

\begin{tabular}{|l|l|l|l|l|}
\hline \multicolumn{1}{|c|}{ Questionnaires } & \multicolumn{1}{|c|}{ Range r } & \multicolumn{1}{c|}{ Description } & \multicolumn{1}{c|}{$\begin{array}{c}\text { Reliability } \\
\text { Koefisien }\end{array}$} & Description \\
\hline $\begin{array}{l}\text { Intrenal Control } \\
\text { Organizational Culture }\end{array}$ & $0,511-0,897$ & All valid & 0,971 & Reliable \\
Total Quality Management & $0,524-0,884$ & All valid & 0,978 & Reliable \\
\hline Organization Performance & $0,431-0,869$ & All valid & 0,953 & Reliable \\
\hline
\end{tabular}

performance using balanced scorecard model partially and simultaneously on LAZ in Indonesia. The objectives of this search are (1) to find empirical evidence to obtain an answer of research problems (about the effects of the implementation of internal control, organizational culture, and total quality management partially and simultaneously on organizational performance using Balanced scorecard in LAZ in Indonesia. 2) This research can be used by zakat management organizations (OPZ) especially LAZ as a basis to conduct organizational performance using balanced scorecard model which is an assessment model that uses non-financial and financial perspectives. (3) the result of this research can become a reference that constructs the basic model of comprehensive organizational performance assessment for zakat management organisations ( OPZ) in order to increase public trust and the competition power of LAZ, especially LAZDA ( local zakat management organization ) and LAZNAS ( national -wide)

This research is a quantitative research with a research method that has been planned for this research (explanatory research) because this research describes causal relationships between variables (Cooper and Schindler, 2006: 154). Furthermore, in order to acquire the data needed to prove

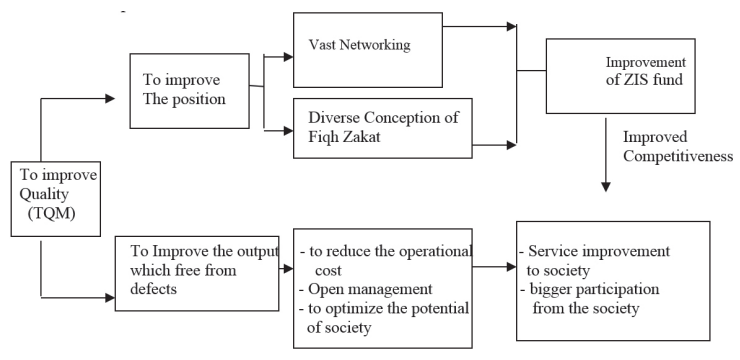

Figure 3: ZIS Fund Management Improvement Strategy With Key Benefits Approach Total Quality Management (TQM)

Source: Budi Budiman: 2002 the hypothesis of the research, by using multiple data collection techniques, the researcher uses questionnaires, interviews and documentation. Meanwhile, data testing conducted are validity and reliability tests with the following results:

The target population of the research is Amil Zakat Institution (registered in the Forum Zakat as an active member comprising LAZNAS and LAZDA registered in Foz as an active member. Proportional sampling technique is Stratified Random Sample. The determination of using Slovin formula with the error rate (d) of 0.05 is 44: Of the target population of $50 \mathrm{LAZ}$, who filled out a questionnaire in this study are $41 \mathrm{LAZ}$, consisting of 14 LAZNAS and 27 LAZDA, while 9 LAZ are not willing to serve as a target population/ respondent. Method of data analysis used in this research is partial least squares. Measurement model latent variable in this study is defined as follows Tabel 1 .

- Latent variable implementation of internal control (reflective)

$$
\begin{array}{ll}
X_{1.1}=\lambda_{1} P I+\delta_{1} & X_{1.4}=\lambda_{4} P I+\delta_{4} \\
X_{1.2}=\lambda_{2} P I+\delta_{2} & X_{1.5}=\lambda_{5} P I+\delta_{5} \\
X_{1.3}=\lambda_{3} P I+\delta_{3} &
\end{array}
$$

- Latent variable implementation of organization culture (reflective)

$$
\begin{array}{lll}
\mathrm{X}_{2.1}=\lambda_{6} & \mathrm{BO}+\delta_{6} & \mathrm{X}_{2.5}=\lambda_{10} \mathrm{BO}+\delta_{10} \\
\mathrm{X}_{2.2}=\lambda_{7} \mathrm{BO}+\delta_{7} & \mathrm{X}_{2.6}=\lambda_{11} \mathrm{BO}+\delta_{11} \\
\mathrm{X}_{2.3}=\lambda_{8} \mathrm{BO}+\delta_{8} & \mathrm{X}_{2.7}=\lambda_{12} \mathrm{BO}+\delta_{12} \\
\mathrm{X}_{2.4}=\lambda_{9} \mathrm{BO}+\delta_{9} &
\end{array}
$$

- Latent variable implementation of total quality management (reflective)

$$
\begin{aligned}
& \mathrm{X}_{3.1}=\lambda_{13} \mathrm{TQM}+\delta_{13} \\
& \mathrm{X}_{3.2}=\lambda_{14} \mathrm{TQM}+\delta_{14} \\
& \mathrm{X}_{3.3}=\lambda_{15} \mathrm{TQM}+\delta_{15}
\end{aligned}
$$

- Latent variable implementation of organization performance (reflective)

$$
\begin{array}{ll}
Y_{1.1}=\lambda_{16} \mathrm{KO}+\varepsilon_{1} & \mathrm{Y}_{1.4}=\lambda_{19} \mathrm{KO}+\varepsilon_{4} \\
\mathrm{Y}_{1.2}=\lambda_{17} \mathrm{KO}+\varepsilon_{2} & \mathrm{Y}_{1.5}=\lambda_{20} \mathrm{KO}+\varepsilon_{5} \\
\mathrm{Y}_{1.3}=\lambda_{18} \mathrm{KO}+\varepsilon_{3} &
\end{array}
$$


Table 2

Recapitulation Average Score of Rate Respondents Regarding Organizational Performance

\begin{tabular}{|l|l|c|c|}
\hline No & \multicolumn{1}{|c|}{ Indicators } & Average Score & Criteria \\
\hline 1 & Customers and Stakeholders & 7,98 & Good \\
2 & Financial & 8,43 & Good \\
3 & Internal Business Process & 8,31 & Good \\
4 & Employees and Organization Capacity & 8,08 & Good \\
\hline
\end{tabular}

Table 3

Recapitulation Average Score of Rate Respondents Regarding Internal Control

\begin{tabular}{|l|l|c|c|}
\hline No & \multicolumn{1}{|c|}{ Indicators } & Average Score & Criteria \\
\hline 1 & Environment Control & 7,51 & Good \\
2 & Risk Assessment & 7,70 & Good \\
3 & Activities Control & 7,83 & Good \\
4 & Information dan Communication & 7,64 & Good \\
5 & Monitoring & 7,40 & Good \\
\hline
\end{tabular}

Table 4

Recapitulation Average Score of Rate Respondents Regarding Organizational Culture

\begin{tabular}{|l|l|c|c|}
\hline No & \multicolumn{1}{|c|}{ Indicators } & Average Score & Criteria \\
\hline 1 & Innovation and Risk Taking & 7,98 & Good \\
2 & Attention to Detail & 8,13 & Good \\
3 & Outcome Orientation & 8,41 & Good \\
4 & People Orientation & 8,03 & Good \\
5 & Team Orientation & 8,11 & Good \\
6 & Agresiveness & 8,09 & Good \\
7 & Stability & 7,40 & Good \\
\hline
\end{tabular}

Tabel 5

Recapitulation Average Score of Rate Respondents Regarding Total Quality Management

\begin{tabular}{|l|l|c|c|}
\hline No & \multicolumn{1}{|c|}{ Indicators } & Average Score & Criteria \\
\hline 1 & Oriented In Customer Satisfaction & 8,36 & Good \\
2 & Empowering and Engaging Employees & 8,16 & Good \\
3 & Continuous Improvement & 8,05 & Good \\
\hline
\end{tabular}

Having described the measurement model of each latent variable, structural model (inner model) describes the specification of the relationship between latent variables, the with equation models follows:

$$
\mathrm{KO}=\gamma_{1.1} \mathrm{PI}+\gamma_{1.2} \mathrm{BO}+\gamma_{1.3} \text { TQM } \mathrm{X}_{3}+\zeta_{1}
$$

In the diagram, the relationship between variables in the hypothesis of the study is presented in figure 5.

\section{Description Organizational Performance}

Organizational performance has four

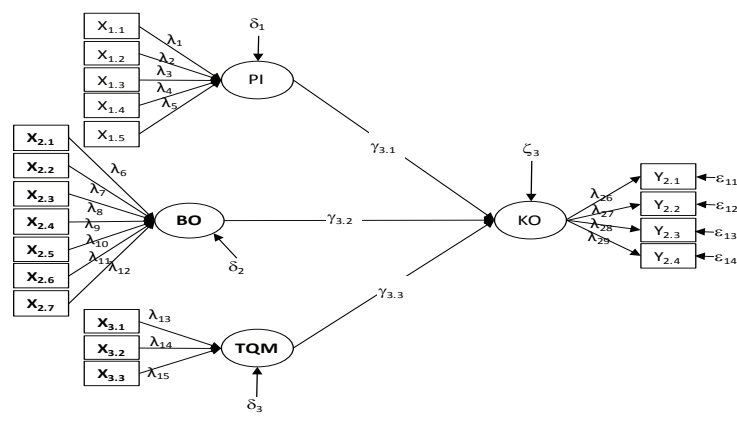

Figure 5 Diagram of Organizational Performance: Implementation of Internal Control, Organizational Culture, and Total Quality Management 
indicators with the average assessment score from the respondents as follows at Table 2. The average total score of respondents on the performance of the organization with four indicators ranging from (7.98 to 8.43 ) in which each criterion indicating that organizational performance assessment in most of the registered LAZ is good.

\section{Description of Internal Control Application}

The application of internal control has five indicators with an average score of respondents' votes as follows at Table 3. The average total score of respondents' assessment of the application of internal control with five indicators ranges from (7.40 to 7.83 ) with the respective criteria indicates that the application of internal control in most LAZ registered in Foz are good.

\section{Description of the Application of Organizational Culture}

The application of organizational culture has seven indicators with an average score of respondents' votes as follows at Table 4.

The average total score of the respondent's assessment on the application of organizational culture with seven indicators ranging from (7.40 to 8.41 ) with the respective criteria indicates that the organizational culture of the majority of $L A Z$ registered in Foz is good.

\section{Description of the Application of Total Quality Management}

The application of Quality Manajemen has three indicators with an average score of respondents' votes as follows at Table 5 .

The average total score of respondents' assessment of the application of internal control with three indicators ranging from (8:05 to 8:36) with their respective criteria, indicates that the application of Total Quality Management in most LAZ registered in Foz are good.

\section{Measurement Model and Structural Model}

The research variables are measured using the indicators, the load factors of each indicator in creating each study variable can be seen in the following Table 6 .

The table shows the load's factor of Composite Reliability of the research variables used are above 0.90 and is still higher than the recommended which is 0.70 . Then, the minimum value of average variance extracted is $(0.713)$ which shows that at minimum $71.3 \%$ of the information in each indicator is represented in each research variable. Meanwhile path coefficient and t statistic value for each path at Tabel 7.

Hypothesis testing The effects of Implementation of Internal Control (PI), Cultural Organization (BO) and Total Quality Management (TQM) on Organizational Performance (KO) Simultaneously.

Through the values in the structural model path diagram between latent variables in Figure 3, the size of the partial influence of an exogenous variable on an endogenous variable can be measured.

Table 6

Loading Factor for Indicators Research Variables

\begin{tabular}{|l|l|c|c|}
\hline No & Variables & $\begin{array}{c}\text { Composite Reliability } \\
\text { (CR) }\end{array}$ & $\begin{array}{c}\text { Average Variance } \\
\text { Extracted (AVE) }\end{array}$ \\
\hline 1 & Organizational Performance (KO) & 0,945 & 0,811 \\
2 & Internal Control (PI) & 0,959 & 0,825 \\
3 & Organizational Culture (BO) & 0,946 & 0,713 \\
\hline 4 & Total Quality Management (TQM) & 0,920 & 0,794 \\
\hline
\end{tabular}

Table 7

Coefficient Path

\begin{tabular}{llrl}
\hline \multicolumn{1}{r}{ Path } & Koefficient & Std.error & T-Statistic* \\
\hline PI->KO & 0.225 & 0.077 & 2.930 \\
BO->KO & 0.336 & 0.096 & 3.512 \\
TQM->KO & 0.200 & 0.063 & 3.167 \\
\hline
\end{tabular}


Table 8

Effect of Variable Application of PI, BO, TQM to KO

\begin{tabular}{|c|c|c|c|c|}
\hline $\begin{array}{c}\text { Laten } \\
\text { Variables }\end{array}$ & $\begin{array}{c}\text { Path Co } \\
\text { efficient }\end{array}$ & Direct Effect & Indirect Effect & $\begin{array}{c}\text { Total } \\
\text { Effect }\end{array}$ \\
\hline PI & 0,225 & $10 \%$ & $2,9 \%$ & $12,9 \%$ \\
BO & 0,336 & $16,6 \%$ & $2,3 \%$ & $18,9 \%$ \\
TQM & 0,200 & $7,8 \%$ & $2,0 \%$ & $7,8 \%$ \\
Simultaneously & & & & $41,60 \%$ \\
\hline
\end{tabular}

Table 9

Significance Test Implementation Effect PI, BO, dan TQM Simultaneously To KO.

\begin{tabular}{|llll|}
\hline Simultaneously Effect & $\mathrm{F}_{\text {count }}$ & $\mathrm{F}_{0,05(3 ; 37)}$ & Conclusion \\
\hline $41,6 \%$ & 8,785 & 2,859 & $\begin{array}{l}\text { there are significant } \\
\text { effect }\end{array}$ \\
\hline
\end{tabular}

Table 10

Significance Test of Effect Implementation PI To KO

\begin{tabular}{|l|l|l|l|}
\hline Path Coefficient & $\mathbf{t}_{\text {-count }}$ & $\mathbf{t}_{\text {-critics }}$ & Conclusion \\
\hline 0,225 & 2,930 & 1,96 & $\begin{array}{l}\text { There are significant } \\
\text { Effect }\end{array}$ \\
\hline
\end{tabular}

Table 11

Significance Test of Effect Implementation BO to KO

\begin{tabular}{|l|l|l|l|}
\hline Path Coefficient & $\mathbf{t}_{\text {-count }}$ & $\mathbf{t}_{\text {-critics }}$ & Conclusion \\
\hline 0,336 & 3,512 & 1,96 & $\begin{array}{l}\text { There are significant } \\
\text { Effect }\end{array}$ \\
\hline
\end{tabular}

Simultaneously, the implementation of PI, BO and TQM variables are able to explain the changes in the organizational performance as much as (41.6\%) and (58.6\%) which is explained by other factors that are not examined. Among the three exogenous variables, the application of $\mathrm{BO}$ gives the biggest contribution to $\mathrm{KO}$.

From the Table 9, it can be seen that Fstatistic is (8. 785) higher than $F$ table (2.859), as the value of $F$ statistic higher than $\mathrm{F}$ table so at the $90 \%$ trust level, it can be concluded simultaneous applications of PI, BO, and TQM have significant effect on KO. Statistical test results are in line with expectations of researchers, namely if the application of PI, BO and TQM are applied optimally then $\mathrm{KO}$ is likely to increase. Statistical test results have proved the existence of a significant effect of the three variables on $\mathrm{KO}$. This result completes the result of Sri Fadilah (2014: 13) by adding organizational culture variable.

Effects of the Implementation of Internal Control on Organizational Performance.

It is hypothesized that the application of internal control has effects on organizational performance. The results of the significance test of the hypothesis are as Table 10.

From the table, the path coefficient of the application of PI on KO is $(0.225)$ with a positive direction. Positive path coefficient shows that the good application of PI tends to increase KO. Furthermore, the value of $t$ statistic (2.930) is bigger than tcritical (1.96) indicates that there is a significant effect of 
Table 12

Significance Test of Effect Implementation TQM to KO

\begin{tabular}{|c|c|c|c|}
\hline Path Coefficient & $\mathbf{t}_{\text {-count }}$ & $\mathbf{t}_{\text {-critics }}$ & Conclusion \\
\hline 0,200 & 3,167 & 1,96 & $\begin{array}{c}\text { There are significant } \\
\text { Effect }\end{array}$ \\
\hline
\end{tabular}

the application of PI on KO. Statistical test results are in line with the expectations of researchers, namely if the application of PI is better, KO is likely to increase. Statistical test results have proved the existence of a significant effect of the application of the PI on KO. The results support the COSO (2004: 13) that becomes the basis for internal control variables.

\section{The Effects of the Application of Organizational Culture on Performance Organization}

It is hypothesized that the application of organizational culture affects organizational performance. The following are the results of the significance test of the hypothesis as follows.

From the Table 11, we can see the path coefficient of BO application on KO is (0.336) with a positive direction. Path Coefficient with positive marks shows that a good application of BO makes a high KO. Furthermore, the value of $t$ statistic (3.512) is bigger than $t$ critical (1.96) which indicates that there is a significant effect of the application of $B O$ on KO. A statistical test result according to the researchers' expectations would be if the application of BO is better, KO would increases. Statistical test results have proved the existence of a significant effect of the application of BO on KO. The result supports the results of flamholtz (2002: 266) and muller \& Rehder (2002: 108).

\section{Effects of Total Quality Management Implementation on Organizational Performance}

It is hypothesized that the application of total quality management influences organizational performance.

The Table 12 shows that the path coefficient of the application of $\mathrm{KO}$ is 0.200 with positive direction. Positive path coefficient indicates that a good application of TQM leads to a high KO. The value of $t$ statistic (3.167) is bigger than tcritical (1.96) indicates that there is a significant effect of the application of TQM on KO. Statistical test results are in line with the expectations of the researchers. If the application of TQM is better, $\mathrm{KO}$ tends to be higher. Statistical test results have proved the existence of a significant effect of the application of TQM on KO. The results support the results of Samdin (2002: 19), where the implementation of TQM has an effect on KO.

\section{Conclusions}

Based on the previous discussion, some conclusions can be obtained as follows:

Simultaneous variable of internal control application, organizational culture and total quality management are able to explain the changes in the organizational performance as much as (41.6\%) and (58.6\%) and also other explanations by other factors that are not examined.

Partially, the variables of internal control, organizational culture and total quality management applications have a significant effect on organizational performance.

The variable of organizational culture application is a variable that has the biggest effect on organizational performance compared to variables of internal control and total quality management applications.

What the research suggests about internal control is that controlling as internal control component has the lowest respondent value. Controlling has become important because it can give feedback to all activities in the organization.

\section{References}

Apfelthaler Gerard, Hellen J Muller and Robert R Rehder. (2002). Corporate Global Culture as Competitive Advantage: Learning from Germany and Japan in Alabama and Austria. Journal of World Business (JWB). P. 37.108

Budi Budiman,(2002), Potensi Dana ZIS Sebagai Instrumen Ekonomi Islam dari Teori dan Implementasi Manajemen. Makalah disajikan dalam Simposium Nasional Sistem Nasional Ekonomi Islam, 
Yogyakarta. Hal. 16.

Christian Herdinata. (2008). Good Corporate Governance Vs Bad Corporate Governance: Pemenuhan Kepentingan Antara Para Pemegang Saham Mayoritas dan Pemegang Saham Minoritas. Makalah ini disajikan dalam The 2nd National Conference UKWMS Surabaya, 6 September 2008. P.14-15

Committee of Sponsoring Organization (COSO) of The Treadway Commision (2004). Enterprise Risk Management - Integrated Framework: Executive Summary. COSO. September 2004. P. 13

Flamholtz, Eric. (2001). Corporate Culture and The Bottom Line, European Management Journal Vol. 19, No. 3, 2001 Published by Elsevier Science Ltd. All rights reserved Printed in Great Britain 0263-2373/01. pp. 266-275.

Hoque Zahirul. (2003). Total Quality Management and The Balanced Scorecard Approach: A Critical Analysis of Their Potential Relationship and Dirrections for Research. Journal Critical Perspective on Accounting. p.43.

Ikatan Akuntan Indonesia. (2012). Standar Akuntansi Keuangan. Penerbit Salemba Empat. Jakarta p.319-2.

Kaplan. Robert and David P Norton. (1996). The Strategy Focused Organization. Harvard Business School Press. Boston. Massachusetts.p. 102.

Kaplan. Robert and David P Norton. (1996), Menerapkan Strategi Menjadi Aksi: Balanced Scorecard. Dialihbahasakan oleh Peter R Yosi Pasla. Penerbit Erlangga. Jakarta.

Peter R Yosi Pasla and Robbin Cooper. (1998). Cost and Effect: Using Integrated Cost Systems to Drive Profitability and Performance. Harvard Business School Press. Boston.

Kreitner. Robert \& Kinichi Angelo. (2008). Organization Theory and The New Public Administration. Boston. Allyn and Bacon Inc. 72.

Morgan, Robert M and Shelby Hunt. (1994). The Commitment Trust Theory ofRelationship Marketing. Journal of Marketing 58:20-38
Pepper. Don and Rogers Martha. (2004). Managing Customer Relationships. New Jersey; John Wiley \& Sons, Inc.

Robbin, Stephen P. (2010). Organization Theory, Structure, Design and Application. Seventh Edition, Prentice Hall International. Inc. United of America. P. 210.

Rohm. Howard. (2004), Improve Public Sector Result With A Balanced Scorecard: Nine Steps to Success. http//www. balancedscorecard.org.

Samdin. (2002). Motivasi Berzakat: Kajian Manfaat dan Peranan Kelembagaan. Makalah disajikan dalam Simposium Nasional Ekonomi Islam, Yogyakarta. H.19

Samdin. (2002). "Pengembangan Manajemen Bazis." Makalah disajikan dalam Simposium Nasional Ekonomi Islam, Yogyakarta. H.23.

Shamdasni, Prem N and Audrey Balakrishnan. (2000). Determinants of Relationship. Quality and Loyalty in Personalized Services. Asia Pacific Journal of Management. 17:399-22 .

Sirdeshmukh, Deepak; Jaddig Singh; Berry Sabol. (2002). Customer Trust, Value and Loyalty in Relational Exchanges. Journal of Marketing, 66:15-37. Chicago.

Sri Fadilah. (2012). Membangun Kepercayaan Konsumen: Faktor Penting Pada Lembaga Amil Zakat di Indonesia. Makalah disajikan pada SNAPP 2015. LPPM Unisba. Bandung. H. 8.

Amil Zakat di Indonesia (2011). Pengaruh Implementasi Pengendalian Intern dan Total Quality Management Terhadap Penerapan Good Governance. Disajikan pada SNA 14 di Universitas Syiah Kuala Nangroe Aceh Darussalam. H.11.

Tenner, Arthur R and Detoro Irving J. (2008). Total Quality Management. Adison-Wesley publishing company. USA.p.32.

Undang-Undang No 23 Tahun 2011 (2011) tentang Pengelolaan Zakat di Indonesia

Zabid, Abdul Rahid, Murali Sambasivam and Juliana Johari. (2003). The Influence of Corporate Culture and Organization Commitment on Performance. The Journal of Management Development N0.8. 56. 